Tatjana STOJANOSKA-IVANOVA

UDK: 26-42

Review article

\title{
MORAL ASPECTS OF JUDAISM, CHRISTIANITY AND ISLAM
}

\begin{abstract}
In the modern society many factors influence the societal processes. There is no social sphere that can remain untouched by the changes that happen every single day. Besides all the specifics of modern lifestyle, a particular one is the religion as one of the most complex societal phenomena. The modern sociologists of religion share the opinion that in the $21^{\text {st }}$ century as well, in the era of globalization and internet-revolution, the religion is not just losing its path, but is becoming even more established in the societal environment. In the context of religion, the emphasized moral aspects are very significant, especially those of the dominant monotheistic religions (Judaism, Christianity and Islam) as universal human moral values. By accepting these values, a person enriches himself.
\end{abstract}

Key words: RELIGION, MORAL VALUES, JUDAISM, CHRISTIANITY, ISLAM

\section{Introduction}

Modern sociologists of religion are looking for answers to the following dilemmas: Are morality and religion significantly dependent?, Is there a connection between the norms, especially the moral codex, of the universal religions?, Does people's moral behaviour and action reveal their religion?, Do people who declare themselves as atheists internalize the moral codex in a more difficult manner?, Is the moral codex of norms and values directly internalized through religious education and practices?

These dilemmas are especially considered to be modern renewed questions which are of great importance for the life and for the actions of the people today. These dilemmas and questions, showing the connection between religion and morality, were discussed throughout history. In certain time periods and learnings their connection was affirmed. However, their dependence and connection were often negated and rejected.

Two and a half thousand years after Socrates and two thousand and eighteen years after Christ, mankind is far away from being a perfect moral kind, and the world we are living in is even further away from being morally perfect. Despite the fact that science and technology are making great progress, societies are developing very fast and the information technology is an example of development, we still cannot state that societies are perfect. Modern societal development also includes the development of ethics as a system of values. Experiences show that societies with high and modern 
moral values are successful and have a good future. In societies where ethics is not respected and where human and societal values are low, life is without prospects. Many of these societies are technologically advanced, but the problem is that exactly those countries lack morality. Morality is understood as a developed ethical system and social moral norms and as a system of values that will contribute to the proper social development of people. If a society in terms of values is not clearly defined and developed, then there will be a chaotic atmosphere, which means that the affected population will have an insecure future. Without a good vision and without ethical standards, the society and the people living in such a society do not have a future.

In many societies, including ours, radical changes of the codex of moral norms and the value system were made. On the one hand, some norms which were positioned at the end of the hierarchical scale climbed up on the top; on the other hand, other norms that were on the top got marginalized and were positioned at the end of the scale. In a certain period of time, those changes of the moral codex also created a vacuum of the values, namely a period of lack of value criteria. These time periods are exposed to moral corrosion and erosion of the value codex. In a situation like this, there is a great chance that the person, who is in a development phase, does not know and cannot properly decide which way to go because the value system has changed or because there is a vacuum of the moral norms, so he/she is not able to distinguish between right and wrong, nor to decide on what is good and needed for a proper development. In such cases there is a good chance that a person will not develop properly. In such situations in particular, when there is a moral erosion and an improper development of the value system, moral norms that are part of the great universal religious systems should be imparted in order to prevent people from choosing the wrong path.

Moral norms and value systems in societies are an eternal theme of sociologists, especially when there is a crisis of the value system and a moral erosion due to the fact that some norms which were positioned at the end of the hierarchical scale climbed up on the top, and other norms that were on the top got marginalized.

Despite the generally accepted position that values are the most persistent part of a culture and very difficult to change, namely the established value system is firmly rooted in the society, and in times of changes it also comes to a change of the values. The question of the profound values becomes a central topic when the main values are forgotten. Without these main values neither a person is a person, nor life is life. In times of a good societal development with a value system firmly rooted in the society, there is no need for debates and discussions about the profound spiritual values; but in times of crisis with an evident erosion of morality there is a strong need for putting the focus on the profound values and on the questions that are very important for human life. When people get lost in life, only spiritual values can help them to find the right path, otherwise they will get lost in life. This is the reason why norms are needed, however it depends which norms are needed (ethical, moral, religious, legal). All norms are needed for human perfection because human nature should logically advance. In such moments, some sociologist suggest to accept and apply values that are firmly ro- 
oted in the big universal religious systems because they are not changeable and will help people to develop themselves properly.

\section{Moral norms in Judaism, Christianity and Islam}

The need for moral improvement with the help of moral norms, which are part of the religions, as well as the role of the universal religious systems (especially Judaism, Christianity and Islam) in the moral education of mankind, is being emphasized by many scientists. Temkov notes that ethics and religion are fundamental spiritual human powers, which help people build up their meaning of life. Depending on the epoch and the development stadium, ethics and religion give back hope to people (Temkov, 81). The position of Radomir Lukić, who underlines the meaning of morality as a part of religion, is also in this context. According to him, the normative statements in religion describe one of the main elements and those statements are included in the commandments. The moral in religion through the commandments and norms of good behaviour is the foundation for further ethical and spiritual development of a believer (Lukić, 132). The famous sociologist of religion Šušnjić accentuates that morality, which emerges from religion, is a way of putting believers on the right path. Every time God reveals his will to the people, he, actually, shows them the values and the norms of good life (Šušnjić, 239), but God's commandments should be understood as offers, advices, massages or recommendations to live a moral life, not as orders or laws.

The three monotheistic religions, Judaism, Christianity and Islam, include a lot of common elements which refer to moral norms and values and are basic human values. First of all, it is highlighted that the good is the top moral value and that the path to the good is broad, and to the evil is narrow. In this context, the principle of the good as a top moral value becomes established in an explicit way in Judaism, Christianity and in Islam. If you analyse the Holy Scriptures of the three religions, you will find out that the positive moral characteristics are constantly emphasized. Instead of learning negative characteristics like pride, finessing, evilness, malice, adultery, unchastity, meanness and infamousness, every person should learn the positive moral characteristics like modesty, honesty, justice, forbearance and gentleness. Heresy, prostitution and adultery are especially strongly deplored. All three religions put accent on the relationship with parents. It is emphasized that we need to have huge respect for parents, and that we should not harm them in any way because they created us, so we are obliged to treat them only in a positive way. Actually, the principle of good and respect should be fundamental motives of the human behaviour and approach toward our parents.

Quite specific for all three religions is something that we can find in all three religions and it appears through the whole content of every Holy Scripture. It is about values like human kindness, love, justice and temperance. Human kindness as a value represents an all-embracing moral accentuation of this important value. The same applies to love as a feeling connected to human kindness. In addition to human kindness 
and love, there is also the benevolence or help which appears in all three religions. It is about benevolence toward the starving and thirsty people, foreigners, and toward all people who are in trouble and need help.

The convention of justice is also a moral convention and a profound moral value which appears in all three religions. Justice is a moral value and a moral human characteristic, which represents a free way of thinking and acting. Under justice you can also notice human kindness and humanity. Judaism also includes the convention of justice in the prophecy books. In addition to the request for justice, it is also pointed out to the judgement from above for the unjust person. The Old Testament says: If the just man deviates from its justice and acts unjustly, if the just man does all the abominations that are done by the sinner, is he going to be alive?

It is not easy for those who create unjust laws; It is not easy for those who build their own house with injustice and their own rooms with lawlessness. Justice is also mentioned as value in the christian religion. The New Testament says: Just as you want others to do for you, do the same for them; Treat others in the same way that you would want them to treat you. In the context of Islam, especially in the Koran, justice is emphasized as a value and represents the basis of the religion. Justice in Islam does not depict legal or lawful elements; it accentuates the moral dimension. The Surah AlAn'am says: The Word of your Lord, that's the Koran, has been fulfilled in truth and in justice. The Surah An-Nisa' says: Allah commands you to judge with justice when you judge among people.

The principle of temperance is also one of the values that appears in all three religions. In the Old Testament and in the New Testament, temperance is often mentioned through certain obligations, and all wrong actions, which humiliate human kind, are listed. Temperance is a virtue, one of the top conventions being recommended to believers from all three religions - Judaism, Christianity and Islam. Temperance is recommended as a moral convention for all human actions and for every human relation, and greed and cupidity are condemned as negative characteristics.

\section{Conclusion}

Today, living in a tough world, with a lot of dishonesty, immorality, dynamic and fast transformations and in times where benevolence and dignity are slowly vanishing, there is a great need for these moral norms. If we forget the profound values and leave the crucial moral principles, we will completely get lost in life.

There is a lot of evidence for the profound moral norms in Judaism, Christianity and Islam. I will list a few of them, which will prove that these religious systems are ethical systems. First of all, the most dominant value in all three Holy Scriptures is the principle of love and love as the biggest human value. Love is described in the most dignified way, as a feeling that should arise the goodness in every human being, as a feeling that should evoke the most hidden wishes and secrets, as a feeling that should im-

prove and enrich the human soul, simply a feeling that should accompany every person 
in his/her actions and communication with other people. In Judaism, Christianity and Islam, the meaning of love is emphasized and it is accentuated that the people who can give and receive love are blessed - these people will enjoy their time on earth and in heaven. The principle of good, which is a profound moral value, has a very special meaning. Through the whole text of the Holy Scriptures you will notice the view that every man should be led by the principle of good. The good deeds should be praised and respected, and the evil should be rejected and avoided. The good should be the motive for our behaviour and actions. Only by respecting this principle, we can morally climb up to a higher level. The role of family, pointed out in the mentioned religions, is very big, especially during religious holidays. In this case, the meaning of family for every person, the meaning of the parents, as well as the need for a person to grow up and live in a healthy family is accentuated. The values like cosmopolitanism, friendship, benevolence and respect are also crucial points of these religious systems. These values are constantly accentuated. The immoral characteristics, feelings and behaviour like lie, fraud, theft, murder and adultery are denied and rejected in Judaism, Christianity and Islam. 


\section{References}

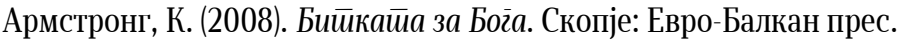

Bouker, Đ. (ed.) (2006). Religije. Novi Sad: Stylos.

Bošnjak, B. (1988). Filozofija krščanstva. Zagreb: Stvarnost.

Bikaj, M. (2003). Biblijata, kuranot i naukata. Skopje: Logos-A.

Vernon, M.G. (1962). Sociology of Religion. New York: McGraw, Hillbook Company.

Верски алманах на Република Македонија. (2010). Скопје: Комисија за односи со верските заедници.

Dačič, S. (2006). „Sociologija religije i verska tolerancija“. Vo Religija i tolerancija. Novi Sad: Čigoja Štampa.

Elijade, M. (1996). Vodić kroz svetske religije. Beograd: Narodna knjiga Alfa.

Expozito, L. (2002). Oksvorska istorija Islama. Beograd: Clio.

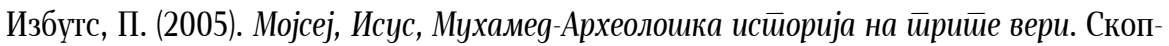
je: AEA.

Keler, Juzef. (2002). Osnivači velikih religija. Beograd: Stoper Book.

Лукић, Р. (1982). Социолог̄uја морала. Београд: Научна књига.

Линк, Т. (2000). Исӣорија религије исйока и зайаgа. Београд: Српска књижевна задруга.

Павичевић, В. (1974). Основи ейике. Београд: БИГЗ.

Pavičevič, V. (1986). Sociologija religije-sa elementima filozofije religije. Beograd: BIGZ.

Temkov, K. (2003). Etika za mlade. Niš: Bajka.

Tompson, K. (2003). Moralna panika. Beograd: Clio.

Haralambos M., Holborn M. (2002). Sociološke teme i perspective. Zagreb: Golden marketing.

Šušnjič, Đ. (1997). Dijalog i tolerancija: Beograd: Čigoja Štampa.

Šušnjič, Đ. (1998). Religija I, II. Beograd: Čigoja. 